\title{
Green Boutique Hotels - Marketing and Economic Benefits
}

\author{
Miroslava Malcheva, PhD Student \\ University of Economics - Varna, Varna, Bulgaria \\ m.malcheva@ue-varna.bg
}

\begin{abstract}
Boutique hotels represent the most luxurious and innovative part of destination "tourist power". They attract a provocative, modern and extremely demanding segment that requires a special attention not only in terms of guests' physical stay, but also in the added value that a hotel of such category should provide to the customers. In this sense, some boutique hotels combine the use of technology-based supply system and marketing approaches with green practices. The environmental responsibility is now an important part of boutique hotels product portfolio and it is considered as a way to increase their economic benefits. As to the marketing, the green concept could be successfully used as a tool for expanding the boutique hotels impact on the tourist market and at the same time to meet the specific needs of eco-conscious consumers. The present study aims to analyze and assess the potential marketing and economic advantages for the boutique hotels that provide differentiated and trade recognized tourist product trough green oriented ideas.
\end{abstract}

Keywords: boutique hotels, green practices, sustainability, marketing, economic benefits

JEL Code: Z300; doi:10.36997/IJUSV-ESS/2019.8.3.179

\section{Introduction}

Tourism is one of the leading growth sectors of the global economy developing countries and destinations but also through the years it has created an increasing amount of stress on the environment. The world is changing, and customer desires are changing too. People began to think about water scarcity, separate garbage collection, global warming and harmful carbon emissions. If no one had heard of eco-friendly hotel certifications as Green Globe International and Green Key Global yesterday, nowadays more and more hotels are introducing technologies and practices that guarantee environmentally friendly and sustainable development and are certified under systems that require active eco-initiatives. While the eco-cause is thought to require a lot of investment, it is more a matter of gestures and behavior that is sufficient for financial profitability. Boutique hotels as properties that would like to provide not only basic accommodation services but also added value for their guest can successfully implement a green idea that will be, in addition a successful marketing tool and a way of reducing overhead expenses and leading of a successful corporate social responsibility policy.

The purpose of the current paper is to identify the green ideas implemented in a boutique hotel product as a competitive advantage for boosting brand image, improving customer loyalty, generating cost savings in the long-term period - all of which translates into higher profits. The goal is realized with the following research tasks: generalization of the main features of the green concept and the effects of its implementation in boutique hotels; using the monitoring method as a basis for summarizing good practices and marketing achievements on a European level; setting up recommendations and guidelines for improving green boutique hotels positions in refer to improve their visibility and hold on the tourism market.

\section{Green practices and eco-friendly attitudes within the hospitality industry.}

The hotel industry has been pursuing green practices since the 1990s due to fluctuating economic levels and a strong focus on customer service (Claver-Cortes et al., 2007). Tourism studies show that the success of the hotel industry is fundamentally tied to a clean and suitable for practicing a variety of activities environment (Thao, 2017). In the beginning of the $21^{\text {st }}$ century the hyper-consumption and the increased levels of travelling became a threat to the environment as much as the heavy industry and the nuclear power. A reflection of this phenomenon is the growth of 
ecotourism and the orientation of the hotel supply to the eco-based experiences and services. Individually, hotels do not have a significant negative impact on the environment. However, collectively they do damage the environment by both consuming and wasting huge amount of resources (Pearson and Parambil, 2019).

In stages, the green consumerism has become a priority of some boutique hotels. As specially positioned entities in the hospitality industry, they provide high-valued services that are a proof of their uniqueness. Greenness is a matter of their perception of today's modernity with all its advantages and disadvantages. Today more and more boutique hotels are implementing the sustainable development concept in their strategies and long-term marketing plans. The ongoing relationship between the hotel industry and the environment brings benefits and harms to both parties (Table 1).

Table 1. Bilateral interaction between the hotel industry and the environment

\begin{tabular}{|c|l|l|}
\hline \multicolumn{1}{|c|}{ Impact } & \multicolumn{1}{|c|}{$\begin{array}{c}\text { Hotel industry impact on } \\
\text { environment }\end{array}$} & \multicolumn{1}{c|}{$\begin{array}{c}\text { Environment impact on the hotel } \\
\text { industry }\end{array}$} \\
\hline \multirow{5}{*}{ POSITIVE } & $\begin{array}{l}\text { Designed so that they could merge in } \\
\text { with the local environment; } \\
\text { Using and promoting organic products } \\
\text { and recycling; } \\
\text { Promoting "green" campaigns. }\end{array}$ & $\begin{array}{l}\text { Educative role in the tourism branch } \\
\text { attitude; } \\
\text { Diversity of activities; } \\
\text { Added value for the guest } \\
\text { (window/balcony views; fresh air). }\end{array}$ \\
\hline \multirow{5}{*}{ NEGATIVE } & $\begin{array}{l}\text { Excessive energy use; } \\
\text { Big percent of waste; } \\
\text { Air pollution; } \\
\text { Noisy hospitality venues; } \\
\text { Land degradation or destruction; } \\
\text { Deforestation. }\end{array}$ & $\begin{array}{l}\text { Restrictions on the territorial expansion of } \\
\text { the business; } \\
\text { Flora and fauna endangering the stay of } \\
\text { guests; } \\
\text { Temporary environmental disasters } \\
\text { preventing access to tourist sites. }\end{array}$ \\
\hline
\end{tabular}

Source: Adapted to: Pearson \& Parambil, 2019; Milanés-Montero et al., 2014.

As the data in the table shows, the hotel industry is doing far more serious environmental damage. This is the reason why some hotels adopt the green concept as part of their product portfolio. The main objectives can be systemized as following (Cámara Santiago de Compostela, 2006):

$\checkmark$ Reduce the consumption of natural resources;

$\checkmark$ Minimize waste production;

$\checkmark$ Avoid accidental contamination;

$\checkmark$ Decrease costs;

$\checkmark$ Improve the environmental management of the organization and the quality of service.

One of the main advantages of applying green concept is that this practice can have a direct reduction in costs by decreasing waste of natural resources, such as energy, water and material resources. The efforts of conservation such as hazardous waste management and water purification will result in a safer workplace that, in turn, may lead to reduced work time lost and a lower risk of taking responsibility. The publicity that is generated when the practices are inadequate can negatively influence the reputation of the hotel and cause operating losses. Instead, good green practices can become an effective promotional tool in an increasingly international market for guests seeking environmentally and socially responsible destinations. As people become more and more aware of the environmental impact of the industry, hotel managers can benefit strategically from increasing their understanding of customers' eco-friendly attitudes (Baker et al., 2014). Sustainability has become an integral part of hospitality strategies and attracts eco-friendly consumers through the implementation of certain mandatory prerequisites such as: installation of water saving systems; introduction of saving and energy efficiency criteria; incorporation of environmental standards in purchases; landscape integration in the environment; respect for the 
environment; information to staff and customers about hotel's environmental policy. As a specific part of the hotel business, increasingly boutique hotels are joining the group of industries with proenvironmental behaviour.

\section{Boutique hotels as promoters of environmental consciousness}

Sustainable luxury was long considered an oxymoron, until recent shifts in the hospitality industry responding to trends in luxury took green travel from niche to necessary (GTA, 2019). The hotel functioning generates series of reflections on the environment (resource depletion, waste, noise), therefore it is very important that this sector establishes a commitment to the environment in order to minimize and reduce the impact of the activity on it. The society has assumed as one of its priorities the interest in the natural environment as a common good to preserve which is the reason why companies, including those, belonging to the hotel sector, adopt a series of measures that guarantee their activities are developed under good environmental management criteria. The main goal is reaching the sustainability in all its dimensions.

Boutique hotels adapt green practices in their work because they (Cámara Santiago de Compostela, 2006):

$>$ Improve the quality of service;

$>$ Increase productivity;

$>$ Reduce the consumption of non-renewable resources (water, energy) and their costs;

$>$ Rationalize the consumption of raw materials;

$>$ Minimize waste, discharges and emissions and their associated cost;

$>$ Improve the public image and prestige;

$>$ Improve the relations with public authorities;

$>$ Establish better access to foreign markets.

The sense of luxury is constantly changing. Boutique hotels are distinguished not only by their original interior and exterior design, but also by their diverse portfolio, striving to be the standard of quality and originality and at the same time to set new trends. While years ago, boutique hotels have been understood as establishments with high-quality business or leisure services, now their role is changed. An extremely high-class boutique hotel has that type of luxury which is devoted to the environment preservation and has an eco-friendly attitude. Many modern boutique hotels are flexible and easily adaptable to innovations, as well as being open to smart solutions, to speed up customer care processes, to optimize hotel operations and to be sustainable.

Many of the boutique hotels that are part of the worldwide recognized Design Hotels Brand go the extra mile for the good of the environment, from solar and geothermal energy to biomass heating technologies and small-scale farm-to-table food programs. A special directory has been created, listing all the boutique sustainability-minded hotels part of the brand, detailing what green certificates they hold, what their eco program is all about and what kind of environmentallytechnologies are used. (Design hotels, 2019).

Taking an ecological approach to hospitality development can bring its own rewards. For sustainable luxury hotels, the rewards are imminent. Eco-conscious millennials are gaining spending power, and their values are driving trends in luxury travel. Millennials are twice as likely to support brands with strong management of environmental and social issues and expect brands to not only manage their impact but communicate it, says Diana Verde Nieto. She is co-founder and CEO of Positive Luxury, an organization that recognizes "luxury lifestyle brands that not only take pride in their craftsmanship, service and design; but also care for their employees and suppliers and work hard to protect our planet". Companies must deliver good social and environmental performance and engage in sustainable practices or their future growth could be at risk (Lee, 2017).

Boutique hotels must have a larger budget to invest in the implementation of new technologies and the creation of successful online marketing campaigns. In this sense, their role in adjusting attitude to the environment reaches many real and potential consumers, and this allows the 
spread of an important and at the same time modern ideology - sustainability and respect to the nature. As a specific type of hotels, the boutique hotels provide the guests with added value beyond the basic service they offer. For green boutique hotels, the added value is precisely the care for guests' healthy lifestyles, the pursuit of environmental protection, the imposition of rules and standards among staff in order to improve service and improve the working environment.

\section{Marketing and economic benefits empowered by green boutique hotels}

Best green practices adapted and promoted by the high-quality hotels have numerous potential benefits (Table 2).

Table 2. Main benefits of applying the green concept by boutique hotels

\begin{tabular}{|c|c|c|}
\hline Categories & Practices & Benefits \\
\hline $\begin{array}{l}\text { Sustainable } \\
\text { site }\end{array}$ & $\begin{array}{c}\text { Sustainable site planning and landscaping } \\
\text { Solar orientation of building } \\
\text { Public transportation } \\
\text { Stormwater management } \\
\end{array}$ & $\begin{array}{l}\text { Reduce environmental impacts } \\
\text { Efficiency of site use } \\
\text { Heat island effect } \\
\text { Reduction of civil infrastructures } \\
\end{array}$ \\
\hline $\begin{array}{l}\text { Energy } \\
\text { efficiency }\end{array}$ & $\begin{array}{c}\text { Solar orientation } \\
\text { High efficiency envelopes (efficient windows and high R- } \\
\text { value insulation) } \\
\text { High efficiency HVAC system } \\
\text { Building automation systems } \\
\text { Daylighting and high efficiency lighting } \\
\text { Onsite renewable energy sources (photovoltaics) }\end{array}$ & $\begin{array}{c}\text { Energy saving } \\
\text { Reduction in greenhouse gases } \\
\text { Lower operating costs }\end{array}$ \\
\hline $\begin{array}{c}\text { Water } \\
\text { efficiency }\end{array}$ & $\begin{array}{c}\text { Water saving fixtures and technologies } \\
\text { Rainwater harvesting system }\end{array}$ & $\begin{array}{c}\text { Water saving } \\
\text { Lower operating costs }\end{array}$ \\
\hline $\begin{array}{l}\text { Materials } \\
\text { and } \\
\text { resources }\end{array}$ & $\begin{array}{c}\text { Green supplies and materials } \\
\text { Construction waste management } \\
\text { Recycled content materials } \\
\text { Regional materials, locally sourced } \\
\text { Rapidly renewable materials }\end{array}$ & $\begin{array}{c}\text { Resource saving } \\
\text { Reduce environmental impacts }\end{array}$ \\
\hline $\begin{array}{c}\text { Indoor } \\
\text { environment } \\
\text { quality }\end{array}$ & $\begin{array}{c}\text { Daylighting \& high efficiency lighting } \\
\text { Adequate air filtration } \\
\text { Low VOC materials } \\
\text { Mold prevention } \\
\text { Enhanced acoustical performance } \\
\end{array}$ & $\begin{array}{l}\text { Productive and healthy indoor spaces } \\
\text { Provide optimal indoor } \\
\text { environment to building users } \\
\text { Improved occupant health and } \\
\text { wellbeing } \\
\end{array}$ \\
\hline $\begin{array}{c}\text { Building } \\
\text { operations } \\
\text { and } \\
\text { maintenance }\end{array}$ & $\begin{array}{c}\text { Green cleaning supplies } \\
\text { Indoor pest prevention and control } \\
\text { Waste reduction and recycling } \\
\text { Energy and water conservation } \\
\text { Green grounds keeping } \\
\text { Electronic versus paper communication } \\
\text { Guest education/communication program } \\
\end{array}$ & $\begin{array}{l}\text { Reduced environmental impacts } \\
\text { Reduced operational and } \\
\text { maintenance costs }\end{array}$ \\
\hline
\end{tabular}

Source: Ahn et al., 2013.

Despite the setup costs and the possible lengthy return on investment associated with environmental initiatives, the economic benefits usually outweigh the cost of implementation (Graci, S., Kuehnel, J.,2011). The ultimate result of these actions is a win-win situation - to reduce hotel operational costs and harmful environmental impacts (Claver-Cortes et al., 2007).

All mentioned economic benefits give serious competitive advantages to boutique hotels that have embraced the green idea of successfully promoting their product to a larger audience and turning green policy into a powerful marketing tool to attract a new segment of consumers - the green consumers. Over time, green practices in the hospitality industry will become a baseline requirement, particularly as the cost of non-renewable energy continues to rise, regulatory pressure increases, and consumers become more demanding (Graci, S., Kuehnel, J.,2011). Travelers are 
making more eco-friendly choices every year, and that includes opting for a green hotel or hotels with green practices when they are available. Having a few environmentally friendly hotel practices in place can set a property apart from the competition and attract guests concerned with reducing their carbon footprint out on the road (Crown Linen, 2016).

Employees are identified as one of the greatest benefits of going green. The hotel staff, like hotel guests, are increasingly sophisticated and "tuned" into current thinking in society and are far more likely to identify with an employer whose principles and practices are aligned with their values. Environmental programs have proved to be an effective means of generating enthusiasm and motivating staff to work as a team to achieve a common purpose. The typical hotel guest of today is more sophisticated and to varying degrees is likely to be concerned about environmental issues. The implementation of environmental initiatives may play a smaller role in a guest's choice of a property. Despite first-time guests basing their decisions on location, amenities and service, customer loyalty may increase once they have experienced a boutique hotel which has demonstrated a level of environmental commitment (Graci, S., Kuehnel, J.,2011).

\section{Literature review and methodology}

Luxury boutique hotels represent high-quality guesthouses that are above the average level of accommodation supply (Ahn et al., 2013). Those hotels usually are characterized with intimate and unconventional environment, by principle, with a luxury denotation. They offer, unlike large hotel chains, personalized services and attention, great privacy and are equipped with extraordinary facilities. They are usually set in a specific style or theme. The purpose of boutique hotels is to make the customer feel at home. They seek to create a unique experience for the client. The exclusivity offered by this type of accommodation is one of its main characteristics. Being small hotels, generally less than 100 rooms, intimacy and privacy are guaranteed. In addition, the environment where they are located makes a difference with other types of accommodation. Guests are looking for quality accommodation where exclusivity is a prime need. An exclusivity that not only is measured by the service offered, but also by the environment that emanates from its facilities, in addition to the environment where the hotel is located: the history of the area, of the building, the respect for preserving this history, the harmony with its surroundings, the exquisiteness in its decoration, the care in its details, an attention that makes the customer feel part of the family. In short, to be able to live a global experience, which experience is not limited to what happened between the walls of the room (Laboella, 2019). The boutique hotels are the perfect place for that types of travellers who are as individual as the hotels themselves and they are looking for experiences, not just accommodation. The guests are not only paying for the comfort and location, but also for the service and the added value (Malcheva, 2018).

Nowadays, a part of their long-term developing strategies is the sustainability. Environmental awareness has a positive effect not only on the nature itself, but also on the hospitality business, by attracting more and more proenvironmental tuned consumers. Sustainability is the base of the social responsibility of the hotel companies and has become the main strategic tool which contributes to the positioning of organizations, when it generates equity and social benefit (Cuadrado et al., 2017). When considering the sustainability of destinations and their successful management, respecting the socio-cultural, environmental and economic aspects of it, we always have to bear in mind its different load capacities and the importance of the participation of the local community at all times of this development, consider also that the long-term perspective is taken into account permanently and that future generations can continue to enjoy a destination of quality, at least the same, which is enjoyed at this time (Gándara et al., 2017). Within the tourist activity, the hotel industry is one of the key elements and due to this fact, in the construction of sustainable destinations, the sustainability of the hotels in this destination becomes a fundamental requisite. The quality of hotel companies and products are important instruments for the touristic territory development. 
According to the Green Hotel Association green hotels are environmentally friendly properties whose managers are eager to institute programs that save water, save energy and reduce solid waste - while saving money - to help protect the earth. After Tourism Council Australia the idea of green hotel is to provide natural accommodation and facility including green services, green products, and fresh and comfortable environment (Wiastuti, 2019). Being a green hotel does not mean compromising on guest satisfaction or the performance of products and services. Any environmentally responsible product or service must work well, or it is of no value, so guests should be as satisfied with the green features in a hotel as with more conventional ones. Being green also does not apply just to high-end properties, on the incorrect assumption that green products are necessarily more costly. Many environmentally responsible products and procedures can be purchased or applied quite economically, especially if cost is considered over their full life cycle (some such products may cost more initially but have much lower operational and maintenance costs, resulting in great savings overall). Finally, being green is not necessarily a single state or endcondition, but rather a process of continuous improvement above a minimum threshold as technologies and procedures develop (Weissman, 2008).

The implementation of the green concept by boutique hotels requires detailed knowledge of environmental changes and the possibilities to minimize their negative effects. In the purposed by the author conceptual model the focus is put on the boutique hotels as promoters of environmental consciousness (Fig. 1). For being a promoter of good environmental practices, it is required the hotel management's will to commit itself to the dissemination of green ideas.

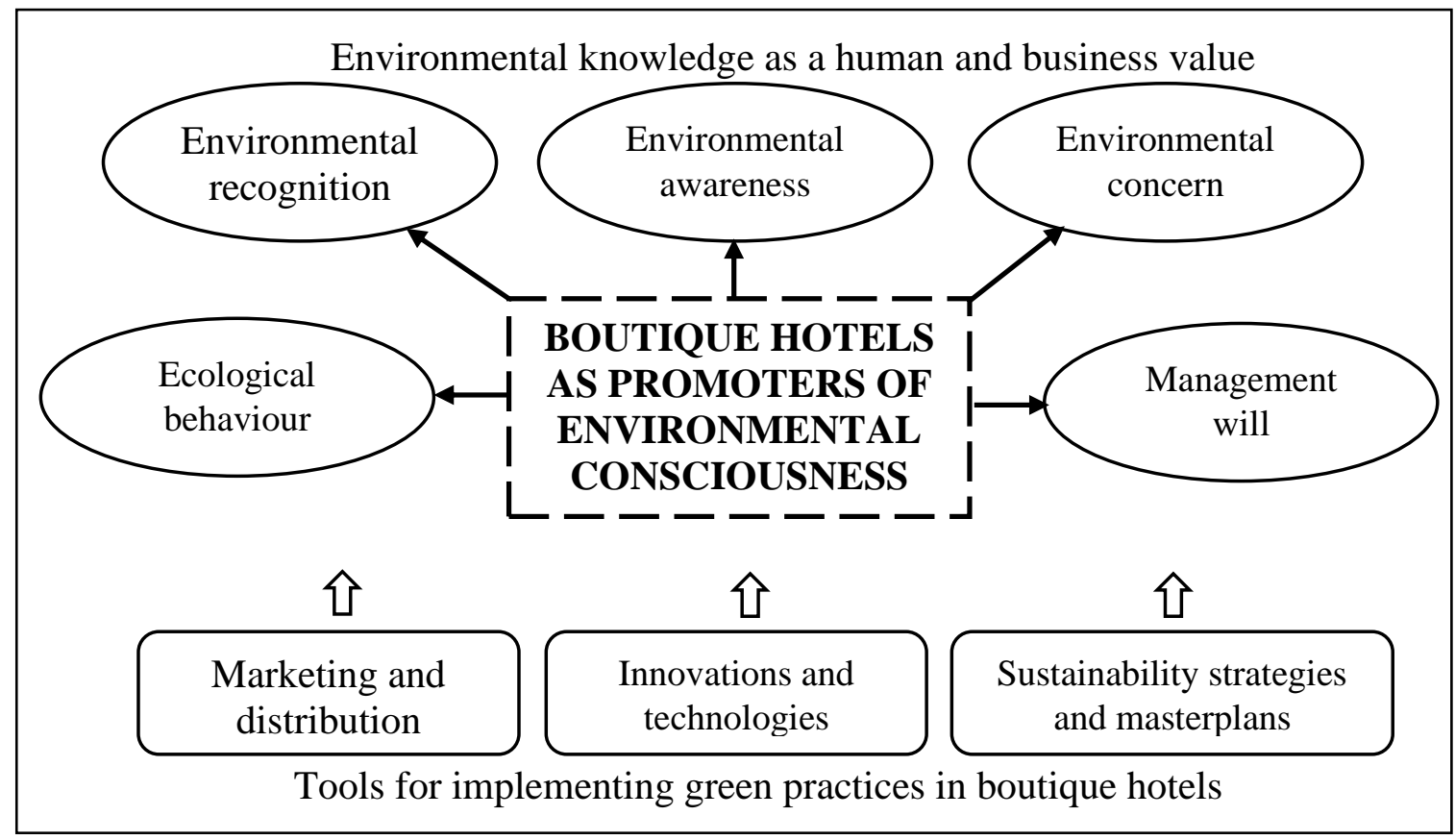

Fig.1. Conceptual model for evaluating boutique hotels' environmental commitment

For being a promoter of good environmental practices, it is required the hotel management's will to commit itself to the dissemination of green ideas. The tools for achieving this goal are related to the application of different marketing approaches (online and offline), the incorporation of greenness into the hotel's plans and strategies for long-term development, as well as the application of innovations and new technologies in hotel services. The current study was developed using the observation method. In October and November 2019 were toured, examined and explored some green boutique hotels in three European cities - Varna (Bulgaria), Barcelona (Spain) and London (United Kingdom). As basic similarities of these hotels can be mentioned the knowledge of the environmental issues and the concern for these problems in three aspects: guests concern, staff 
concern and hotel's management concern. The author's hypothesis is that boutique hotels are the ideal market segment that can apply innovative green practices and, thus, to bring up values and correct attitude towards nature.

\section{Green practices implemented by boutique hotels as a process of knowledge and innovation}

To truly make a difference for the environment and gain a competitive edge, hoteliers need to do more than the bare minimum. Sustainability must be more than just box-ticking green issues your values and policies must demonstrate your true commitment to the cause. While some hoteliers believe they cannot afford to be sustainable or that their guests are not interested in their efforts, the opposite is in fact true. Travelers are increasingly seeking out ecofriendly travel options, and some are even willing to pay extra to support a hotel's sustainability program. According to booking.com, $68 \%$ of global travelers intend to stay at an eco-accommodation in 2018 (Smartvatten, 2019).

Green boutique hotels are eco-smart and innovative and also people friendly. Sustainable hotels treat their staff well and care about their local community. In this way, the hotel guarantees a workforce that stays longer, so employees are happier and more productive. The implementation of green ideas is a multifaceted process that involves taking initiatives from both the top management level and regular hotel staff. All hotel staff need to be involved and take care of nature using simple but effective methods of saving resources and reducing pollution. Without the support of the employees, the eco-program is less likely to be successfully implemented and applied, so it is imperative that the boutique hotel management engages and consults with the employees before starting and during the environmental program development and implementation phase. Employees have knowledge and experience in the specific area and department in which they work and can provide useful feedback for minor improvements that could result in larger savings.

The basic green ideas that are popular and most often implemented in the visited green boutique hotels can be summarized as follows:

$>$ Reducing energy and water consumption - solar panels; green energy; automatic sensors; energy-saving light bulbs and energy-saving lighting and air-conditioning solutions; water-saving aerators in the bathrooms of the hotel, which reduce the amount of water consumed; dispensers for sinks and showers for more efficient use of water;

$>$ Low-carbon buildings - new or newly renovated hotels are low-carbon buildings, thanks to solar panels and innovative technologies;

$>$ Carbon food-print - guests can determine how often their linen and towels are changed;

$>$ Recycling and waste reduction;

$>$ Bath amenities and toiletries - degradable packaging of hotel cosmetics; cosmetics with $100 \%$ natural ingredients;

$>$ Cleaning products - minimal chemicals and fragrances are used in daily cleaning of hotel rooms and in the laundry of hotel linen;

$>$ Products from recycled paper - $100 \%$ recycled paper is used in the hotel offices and for the packaging of hotel accessories;

$>$ Food preparation and food waste - use of local food manufacturers; use of bio products where possible; no disposable utensils;

> Bottled water alternatives - only glass bottle water in the guestrooms;

$>$ Donations - donations to environmental organizations and support of local eco-initiatives and programs;

$>$ Food sharing programs;

$>$ Green mobility - charging stations for electric vehicles, offer bicycles to guests as a green way of traveling;

Live potted plants in all common areas. 
According to the good practices in the visited by the author green boutique hotels, some specific interesting and not so traditional ,go green" recommendations could be made as follows:

$>$ Built beehives to produce own honey;

$>$ Banned the use of overfished species in the hotel restaurants;

$>$ Do not use plastic straws;

$>$ Organize conservation events with the participation of the entire team - tree planting, site cleaning, educational events;

$>$ Reduce heating by 1-2 degrees in public areas;

$>$ Instead of simply throwing used bars of soap away, put all that soap into good use in less developed countries;

$>$ Use paper key cards instead of plastic ones;

$>$ Provide information brochures in every room on environment;

$>$ Provide a self-service application - a huge relief to hotel paper waste as all transactions remain in the guest's digital wallet where they can access them if needed;

Provide $100 \%$ organic cotton linens;

Properly implemented and used, such eco-initiatives at the hotel will help to manage the resources that are used more efficiently and reduce much of the maintenance expenses. Last but not least, they will help the hotel build an eco-brand that guests will remember and look for. The continuous interconnection and exchange between the environment and the hotel industry are a complex process that is reflected in several aspects. On the one hand, the implementation of green practices helps the boutique hotel to position itself on the international market as a carrier of modern values and a "friend" of nature. On the other hand, the green idea attracts and retains a specific market segment, which is distinguished by the following characteristics: high requirements for quality/price ratio; uniqueness and exclusivity of supply; outstanding, memorable service experience; pursuit of modern trends in all their forms: interior design, lifestyle, healthy food, bio products, strengthening the human-nature relationship. In this sense, the boutique hotel fully satisfies the customer`s worldview, i.e. it has the potential to increase the number of its loyal guests. Next, by participating directly in the consumption of eco-friendly services, the guests enhance their personal consumer utility and leave the hotel with the feeling that they have contributed to protecting the environment and/or minimizing its contemporary problems.

\section{Conclusion}

Society is increasingly concerned about its health and well-being as well as the environment. Sustainable development topics are becoming more popular and many guests are relying on ecofriendly brands. Eco-consciousness is on the rise in the field of hospitality and costs savings through implementation of a green program improves business results. Guests are looking for sustainable and authentic experiences and the boutique hotels are beginning to apply green practices not only to energy-saving devices but also to eco-design. The most important investment in setting up a green boutique hotel is related to the environmental policy it wants to pursue. Well-built infrastructure with adaptability for easy introduction of new technologies in the guest rooms and in the common areas guarantees that in the future the green boutique hotel will be in line with the latest trends. The green marketing is a powerful tool for achieving a competitive advantage on the among the boutique hotels. Promoting green practices, satisfying guests environmentally friendly needs, demonstrating social responsibility are key factors for market expansion.

\section{References}

1. Ahn, Y., Pearce, A. (2013) Green luxury: a case study of two green hotels. Journal of Green Building. 8 (1). pp. 90-119.

2. Baker, M., Davis, E. and Weaver, P. (2014) Eco-friendly Attitudes, Barriers to Participation, and Differences in Behavior at Green Hotels. Cornell Hospitality Quarterly. 55 (1). pp. 89-99. 
3. Claver-Cortes, E., Molina-Azorin, J.F. PereiraMoliner and J., Lopez-Gamero, M.D. (2007) Environmental Strategies and Their Impact on Hotel Performance. Journal of Sustainable Tourism 15 (6). pp. 663-679.

4. Crown Linen. (2016) 5 Green Hotel Practices that Impress Guests. [Online] Available from: http://bit.ly/2OK2WjC [Accessed 25/11/2019].

5. Cuadrado, C. and Pacheco, S. (2017) Responsabilidad social empresarial de hoteles boutique y cinco estrellas en Cartagena de Indias. Sotavento M.B.A. 1 (29). pp. 94-102.

6. Design Hotels. (2019) The clean art of traveling green. [Online] Available from: https://www.designhotels.com/inspirations/green-hotels [Accessed 25/11/2019].

7. Gándara, J., Brea, J. and González, M. (2007) El comportamiento de la empresa ante entornos dinámicos. XIX Congreso anual y XV Congreso Hispano Francés de AEDEM. 2. pp. 1-19.

8. Graci, S. and Kuehnel, J. (2011) How to increase your bottom line by going green. [Online] Available from: http://bit.ly/331Vj8B [Accessed 25/11/2019].

9. GTA. (2019) Millennials Demand Green Luxury. [Online] Available from: http://bit.ly/34eOiYo [Accessed 25/11/2019].

10. Laboella. (2019)

11. Malcheva, M. (2018) Competitive advantages of boutique hotels in the context of a sharing economy. Izvestia Journal of the Union of Scientists - Varna 7 (3) pp. 71-83.

12. Milanés-Montero, P., Stone, C. and Pérez-Calderón, E. (2014) Environmental reporting in the hospitality industry: an international analysis. Environmental Engineering and Management Journal. 13 (10). pp. 2531-2540.

13. Lee, D. (2017) Luxury hotels go green as millennials demand sustainable travel options. [Online] Available from: http://bit.ly/331X1a1 [Accessed 25/11/2019].

14. Pearon, S. and Parambil, M. (2019) Hotel Industry and Environmental Impact. [Online] Available from: http://bit.ly/2OGYPoE [Accessed 25/11/2019].

15. Smartvatten. (2019) The ultimate guide to sustainable hotel practices. [Online] Available from: http://bit.ly/37wY2iA [Accessed 25/11/2019].

16. Thao, N. (2017) The Relationship between Eco-friendly Practices and Attitudes toward Green Hotels for Domestic Tourists. VNU Journal of Science: Economics and Business. 33 (2). pp. 101-111.

17. Cámara Santiago de Compostela (2006) Buenas prácticas ambientales en el sector hotelero. [Online] Available from: http://bit.ly/2KRQddB [Accessed 25/11/2019].

18. Weissman, A. (2008) A Complete Overview: What is a Green Hotel? [Online] Available from: http://bit.ly/2qGyMWA [Accessed 25/11/2019].

19. Wiastuti, R. (2014) Do you know 'green hotel? [Online] Available from: http://bit.ly/2QOgpK6 [Accessed 25/11/2019]. 